\title{
Sub-lethal Dose Reponses of Native Polyhydroviruses and Spinosad for Economical and Sustainable Management of Spodoptera litura in Pakistan
}

\author{
Jam Nazeer Ahmad ${ }^{1,2 *}$, Rashid Mushtaq ${ }^{1}$, Samina Jam Nazeer Ahmad ${ }^{1,2 *}$ \\ Mubasher Ahmad Malik', Mujahid Manzoor ${ }^{1}$, Muhammad Tahir ${ }^{2}$, \\ Zubair Aslam $^{4}$, Sumaira Maqsood ${ }^{5}$, Ishita Ahuja ${ }^{3}$ and Atle M. Bones ${ }^{3}$ \\ ${ }^{1}$ Integrated Genomics, Cellular, Developmental and Biotechnology Lab, PARS, \\ Department of Entomology, University of Agriculture, Faisalabad, 38000, Pakistan \\ ${ }^{2}$ Plant Stress Physiology and Molecular Biology Lab, PARS, Department of Botany, \\ University of Agriculture, Faisalabad, 38000, Pakistan \\ ${ }^{3}$ Department of Biology, Norwegian University of Science and Technology, \\ Trondheim, Norway \\ ${ }^{4}$ Department of Agronomy, University of Agriculture, Faisalabad, 38000, Pakistan \\ ${ }^{5}$ Institute of Agricultural Sciences, University of the Punjab, Lahore, Pakistan
}

Article Information
Received 19 December 2018
Revised 23 June 2019
Accepted 21 October 2019
Available online 28 February 2020
Authors' Contribution
JNA, RM and SJNA designed and con-
ducted the experiment. RM, MAM,
SJNA and JNA wrote the manuscript.
JNA, MAM, IA and AMB analyzed
the results. SJNA, AMB, MM, MT, ZA
SM critically reviewed the manuscript.
Key words
Spodoptera litura,
Nucleopolyhedrovirus, Spinosad,
mortality, Synergism, Pest
management

Received 19 Decemben

Revised 23 June 2019

Accepted 21 October 201

Available online 28 February 2020

Authors' Contribution ducted the experiment. RM, MAM, SJNA and JNA wrote the manuscript. JNA, MAM, IA and AMB analyzed the results. SJNA, AMB, MM, MT, ZA

A B S T R A C T

In the present investigation, laboratory trials were conducted to investigate the synergistic, additive or antagonistic effect of three sub-lethal dose rates $\left(2 \times 10^{3}, 4.5 \times 10^{3}\right.$, and $\left.6 \times 10^{3} \mathrm{PIB} / \mathrm{Larva}\right)$ of native isolated Nucleopolyhydrovirus (NPV) from Spodoptera litura and Spinosad $(0.01 \mathrm{ppm})$ against $3^{\text {rd }}$ and $4^{\text {th }}$ instar larvae collected from three different geographical areas of Punjab (Pakistan). A difference in larval mortality, pupation, adult emergence and egg ecluson was observed. The higher but sub-lethal dose rate of NPV with Spinosad exhibited synergistic interaction, while the rest of the combinations were found additive in all the tested populations. The results confirmed the population of $S$. litura from Rahim Yar Khan Region least susceptible, and that of Faisalabad highly susceptible. It may be inferred that the mixtures of the correct sub-lethal doses of Spinoad and NPV in combination may be used against destructive pests such as S. litura. This strategy also has a great potential in insecticide resistance management (IRPM) against such pests in vegetable and major crop growing areas of Pakistan.

\section{Spodoptera litura, \\ mortality, Synergism, Pest}

\section{INTRODUCTION}

$S^{\prime}$ podoptera litura (Lepidoptera, Noctuidae) also known $\mathcal{O}$ as a tobacco caterpillar is a serious polyphagous and cosmopolitan insect pest of vegetable and ornamental crops (Nathan and Kalaivani, 2005; Shaurub et al., 2014; Trang and Chaudhari, 2002). This insect pest attacks leaves, buds and flowers resulting in a serious decline in terms of quality and quantity of the produce. Its management on Brassica crops has become a challenge due to its high reproductive rate as well as damage potential. It has been estimated that S. litura can cause 25-100\% economic losses (Dhir et al., 1992; Prayogo et al., 2005). Farmers mostly rely on use of synthetic insecticides to curb this insect pest, which causes

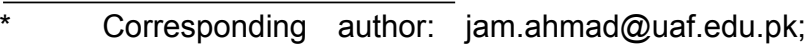
saminatmalik@yahoo.com 0030-9923/2020/0003-0989 \$ 9.00/0

Copyright 2020 Zoological Society of Pakistan
}

serious hazardous threats to environment, human health, and development of resistance in insect pests along with harmful residual effects on wild life (Aydin and Gürkan, 2006). An indiscriminate use of chemical insecticides has resulted in insecticide resistance in $S$. litura population in Pakistan (Ahmad et al., 2007; Ahmad et al., 2008; Shad et al., 2012). It is important to explore different ecofriendly alternatives as use of nucleopolyhedrosis virus successfully reduced $S$. litura population (Ahmad et al., 2018). Recently, various pests and diseases of different crops have been identified from Pakistan for their proper control (Ahmad et al., 2019a, b; Shareef et al., 2019; Ahmad et al., 2019; Ahmad et al., 2017; Manzoor et al., 2018)

The use of biocontrol agents like baculoviruses especially against the important agricultural and forest pests is a pesticide alternative control method, which is completely eco-friendly and environmentally benign (Popham et al., 2016; Rao et al., 2015; Tang et al., 2011; 
Ahmad et al., 2018). The Baculoviridae comprises of 600 viruses, including two genera, the NPVs and the granuloviruses (Hu et al., 2003). The cuboidal shaped NPV is host specific and used as a safe microbial pesticide. Under favorable conditions, it multiplies in the field and reduces the natural pest population (Kumari and Singh, 2009). NPVs have great potential against Lepidoptera insects (Kumari and Singh, 2009; Rios-Velasco et al., 2011; Tang et al., 2011; Zhang et al., 2015).

Spinosad (Sp) is a natural derived mixture of two macrocylic lactones spinosyns A and D produced during fermentation of bacterium Saccharopolyspora spinosa (Mertz and Yao, 1990; Aydin and Gürkan, 2006). The Environmental Protection Agency of U.S. has classified Sp. as a reduced-risk compound due to its environmentally benign characteristics. Spinosad in contrast to synthetic insecticides have low mammalian toxicity and no toxic effect on non-target organisms (Sparks et al., 1998). Due to its safer mode of action and compatibility with NPV, the mixture of Spinosad+NPVs have been evaluated successfully against lepidopteron insect pests (Jackson et al., 2014; Mendez et al., 2002; Figueroa et al., 2015; Wang et al., 2013).

Several studies have been reported in which the synthetic insecticides in combination with virus occlusion bodies enhance the effect of baculoviruses, especially against Lymantria dispar (Cook et al., 1996), S. litura (Nathan and Kalaivani, 2005; Nathan and Kalaivani, 2006; Shaurub et al. 2014; Trang and Chaudhari, 2002), H. armigera (Arrizubieta et al., 2016; Wakil et al., 2012), and Pieris brassicae (Lepidoptera: Noctuidae) (Bhandari et al., 2009). Therefore, keeping in view the importance of low input based crop production and reduction of pesticide load on the vegetable crops, the present study was undertaken to isolate native NPV and to assess their efficacy individually or in combination with commercially available Spinosad against larvae of S. litura from selected districts of Punjab province, Pakistan.

\section{MATERIAL AND METHODS}

\section{Insect culture}

The $S$. litura larvae used in bioassays were collected from crop fields from, Faisalabad, Rahim Yar Khan and Layyah districts of Punjab, Pakistan. The larvae were identified, and mass reared in the Integrated Genomics Cellular Developmental and Biotechnology (IGCDB) laboratory, Department of Entomology, University of Agriculture (UAF), Faisalabad, Pakistan (Fig. 1) at $25 \pm$ $2^{\circ} \mathrm{C}, 75 \% \mathrm{RH}$ and a photoperiod of 14:10 h (L: D) (Fig. 1A) following the method of Saljoqi et al. (2015) and Ahmad et al. (2018) with slight modification. The artificial diets consisted of chickpea flour $150 \mathrm{~g}$, sorbic acid 0.75 $\mathrm{g}$, yeast powder $24 \mathrm{~g}$, agar $8.4 \mathrm{~g}$, vitamin mixture $5 \mathrm{ml}$, ascorbic acid $2.35 \mathrm{~g}$, methl-4-hydroxy benzoate $1.5 \mathrm{~g}$, d $\mathrm{H} 2 \mathrm{O} 550 \mathrm{ml}$ and streptomycin $0.75 \mathrm{~g}$. The diet was stored at $4^{\circ} \mathrm{C}$ until use.
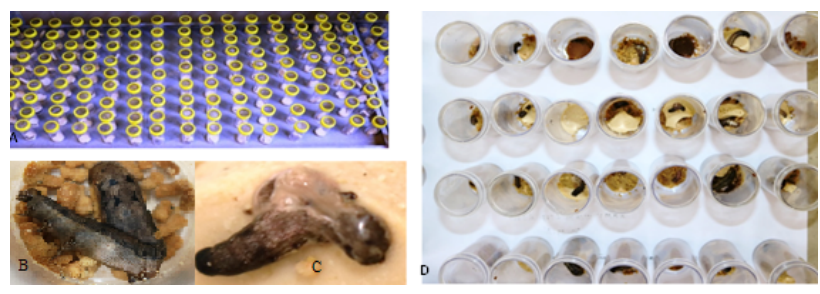

Fig. 1. A, Artificial Rearing of Spodoptera litura on artificial diet under laboratory conditions; B, NPV infected larvae of S. litura collected from cotton field (RY Khan) and $\mathbf{C}$, propagated in laboratory; D, Mass culturing of NPV infected larvae through feeding on diet mixed with NPV suspension.

\section{Insecticide}

The commercial liquid formulation of Spinosad (Dow AgroSciences, Pakistan), containing a spinosyn A to spinosad D ratio of approximately $85: 15$ was prepared.

\section{Viral isolation, suspension preparation and treatments}

The $3^{\text {rd }}$ and $4^{\text {th }}$ instar larvae of $S$. litura from different districts of Punjab were collected and stored in IGCDB laboratory, Department of Entomology, UAF, Faisalabad. The NPVs from S. litura infected insects (Fig. 1B) from Rahim Yar Khan, Multan, Faisalabad and DG Khan Districts were identified on molecular level (Ahmad et al., 2018). In this study, we used isolate RY7 of NPVs collected from Rahim Yar Khan District. For mass culturing, the infected larvae suspension from Rahim Yar Khan was mixed in artificial diet (Fig. 1D). The infected cadavers were homogenized in distilled water and filtered through 3 layers of muslin cloth to remove large debris, then; suspension was centrifuged at $16000 \mathrm{~g}$ for $45 \mathrm{~min}$ (Shapiro et al., 2005; Green et al., 2006). For purification of virus, the pellets were washed three times and kept at $5^{\circ} \mathrm{C}$. The concentration of polyhedral occlusion bodies (POBs) as stock solution $\left(2 \times 10^{8} \mathrm{POB} \mathrm{L}^{-1}\right),\left(3 \times 10^{8} \mathrm{POB} \mathrm{L}^{-1}\right)$, and $\left(4 \times 10^{8} \mathrm{POB} \mathrm{L}^{-1}\right)$ were prepared from indigenous NPV using Neubauer haemocytometer. From stock solution, 1 $\mathrm{ml}$ suspension from each concentration were prepared as NPV1 $\left(2 \times 10^{5}\right.$ POB mL $\left.{ }^{-1}\right)$, NPV2 $\left(3 \times 10^{5} \mathrm{POB} \mathrm{mL}^{-1}\right)$, and NPV3 $\left(4 \times 10^{5} \mathrm{POB} \mathrm{mL} \mathrm{m}^{-1}\right)$. For bioassay, $10 \mu \mathrm{NPV}-1$ ( $2 \times 10^{3}$ POB/larva), $15 \mu \mathrm{l} \mathrm{NPV-2} \mathrm{(4.5} \mathrm{x} 10^{3} \mathrm{POB} /$ larva) and $20 \mu \mathrm{l} \mathrm{NPV-3}\left(6 \times 10^{3} \mathrm{POB} /\right.$ larva) were used to study synergistic, additive or antagonism effect against $S$. litura test population belonging to distinct geographical area of Punjab, Pakistan. 
Table I. Larval mortality ( $\% \pm$ SE) of third-instar larvae of $S$. litura from three different field populations of Punjab province, Pakistan after treatment with NPV and Sp, individually, and in combination (NPV+Sp).

\begin{tabular}{|c|c|c|c|c|c|c|c|c|c|}
\hline \multicolumn{4}{|c|}{ Treatments Actual mortality } & \multicolumn{3}{|c|}{ Expected mortality } & \multicolumn{3}{|c|}{ CTF and type of interaction } \\
\hline & Faisalabad & Layyah & RYK & Faisalabad & Layyah & RYK & Faisalabad & Layyah & RYK \\
\hline Control & $4.8 \pm 1.19 \mathrm{G}$ & $3.7 \pm 1.25 \mathrm{G}$ & $2.4 \pm 1.19 \mathrm{E}$ & & & & & & \\
\hline NPV1 & $21.6 \pm 2.28 \mathrm{~F}$ & $13.6 \pm 2.47 \mathrm{~F}$ & $9.57 \pm 3.41 \mathrm{E}$ & & & & & & \\
\hline NPV2 & $27.8 \pm 2.38 \mathrm{H}$ & $23.5 \pm 2.09 \mathrm{E}$ & $20.31 \pm 3.1 \mathrm{D}$ & & & & & & \\
\hline NPV3 & $32.4 \pm 2.37 \mathrm{E}$ & $29.7 \pm 1.76 \mathrm{E}$ & $31.0 \pm 1.45 \mathrm{C}$ & & & & & & \\
\hline $\mathrm{Sp}$ & $47.9 \pm 1.87 \mathrm{D}$ & $42.6 \pm 1.88 \mathrm{D}$ & $40.05 \pm 2.1 \mathrm{C}$ & & & & & & \\
\hline $\mathrm{NPV} 1+\mathrm{Sp}$ & $65.0 \pm 2.2 \mathrm{C}$ & $57.2 \pm 1.16 \mathrm{C}$ & $39.3 \pm 2.24 \mathrm{C}$ & 69.6 & 56.3 & 49.7 & $\begin{array}{l}-6.5 \\
\text { (Additive) }\end{array}$ & $\begin{array}{l}1.7 \\
\text { (Additive) }\end{array}$ & $\begin{array}{l}-21.5 \\
\text { (Antagonistic) }\end{array}$ \\
\hline $\mathrm{NPV} 2+\mathrm{Sp}$ & $86.0 \pm 2.38 \mathrm{~B}$ & $68.7 \pm 1.23 \mathrm{~B}$ & $68.9 \pm 1.30 \mathrm{~B}$ & 75.8 & 66.1 & 60 & $\begin{array}{l}13.5 \\
\text { (Additive) }\end{array}$ & $\begin{array}{l}3.8 \\
\text { (Additive) }\end{array}$ & $\begin{array}{l}13.8 \\
\text { (Additive) }\end{array}$ \\
\hline NPV3+Sp & $97.7 \pm 1.13 \mathrm{~A}$ & $91.5 \pm 2.29 \mathrm{~A}$ & $86.3 \pm 1.57 \mathrm{~A}$ & 80.4 & 72.3 & 70.8 & $\begin{array}{l}21.1 \\
\text { (Synergistic) }\end{array}$ & $\begin{array}{l}26.6 \\
\text { (Synergistic) }\end{array}$ & $\begin{array}{l}22.9 \\
\text { (Synergistic) }\end{array}$ \\
\hline $\mathrm{F}$ & 256 & 264 & 168 & & & & & & \\
\hline DF & 7,71 & 7,71 & 7,71 & & & & & & \\
\hline $\mathrm{P}$ & $<0.01$ & $<0.01$ & $<0.01$ & & & & & & \\
\hline
\end{tabular}

CTF, Co-toxicity factor; Sp, $0.01 \mathrm{ppm}$; NPV-1, $2 \times 10^{3} \mathrm{POB} /$ larva and NPV-2, $4.5 \times 10^{3} \mathrm{PIB} /$ larva; NPV-3, $6 \times 10^{3} \mathrm{PIB} /$ larva. Within columns, means ( \pm SE) sharing the same letter within each population do not differ significantly (Tukey,s test, $\mathrm{P} \leq 0.05$ ). Upper case letters show significance across the columns.

Table II. Larval mortality $(\% \pm \mathrm{SE})$ of fourth-instar larvae of $S$. litura from three different field populations of Punjab province, Pakistan after treatment with NPV and Sp, individually, and in combination (NPV+Sp).

\begin{tabular}{|c|c|c|c|c|c|c|c|c|c|}
\hline \multicolumn{4}{|c|}{ Treatments Actual mortality } & \multicolumn{3}{|c|}{ Expected mortality } & \multicolumn{3}{|c|}{ CTF } \\
\hline & Faisalabad & Layyah & RYK & Faisalabad & Layyah & RYK & Faisalabad & Layyah & RYK \\
\hline Control & $3.2 \pm 1.25 \mathrm{H}$ & $2.4 \pm 1.19 \mathrm{H}$ & $1.6 \pm 1.04 \mathrm{E}$ & & & & & & \\
\hline NPV-1 & $17.5 \pm 2.89 \mathrm{G}$ & $12.8 \pm 2.56 \mathrm{G}$ & $8.9 \pm 1.55 \mathrm{E}$ & & & & & & \\
\hline NPV-2 & $25.9 \pm 1.93 \mathrm{~F}$ & $23.4 \pm 4.54 \mathrm{~F}$ & $17.9 \pm 3.10 \mathrm{D}$ & & & & & & \\
\hline NPV-3 & $29.0 \pm 1.92 \mathrm{E}$ & $32.4 \pm 1.93 \mathrm{E}$ & $25.5 \pm 1.80 \mathrm{D}$ & & & & & & \\
\hline $\mathrm{Sp}$ & $42.2 \pm 2.42 \mathrm{D}$ & $38.6 \pm 3.53 \mathrm{D}$ & $37.5 \pm 2.01 \mathrm{C}$ & & & & & & \\
\hline $\mathrm{NPV}-1+\mathrm{Sp}$ & $59.2 \pm 1.46 \mathrm{C}$ & $57.5 \pm 3.29 \mathrm{C}$ & $35.3 \pm 0.94 \mathrm{C}$ & 59.7 & 51.4 & 46.5 & $\begin{array}{l}-0.85 \\
\text { (Additive) }\end{array}$ & $\begin{array}{l}11.8 \\
\text { (Additive) }\end{array}$ & $\begin{array}{l}-23.9 \\
\text { (Antagonistic) }\end{array}$ \\
\hline $\mathrm{NPV}-2+\mathrm{Sp}$ & $76.9 \pm 2.04 \mathrm{~B}$ & $73.5 \pm 2.84 \mathrm{~B}$ & $63.9 \pm 1.68 \mathrm{~B}$ & 68.2 & 62.0 & 55.5 & $\begin{array}{l}13.5 \\
\text { (Additive) }\end{array}$ & $\begin{array}{l}18.5 \\
\text { (Additive) }\end{array}$ & $\begin{array}{l}15.2 \\
\text { (Additive) }\end{array}$ \\
\hline $\mathrm{NPV}-3+\mathrm{Sp}$ & $92.2 \pm 1.88 \mathrm{~A}$ & $87.1 \pm 1.36$ & $80.3 \pm 2.26$ & 71.2 & 71.1 & 62.9 & $\begin{array}{l}21.1 \\
\text { (Synergist) }\end{array}$ & $\begin{array}{l}22.6 \\
\text { (Synergistic) }\end{array}$ & $\begin{array}{l}27.6 \\
\text { (Synergistic) }\end{array}$ \\
\hline $\mathrm{F}$ & 225 & 107 & 197 & & & & & & \\
\hline DF & 7,71 & 7,71 & 7,71 & & & & & & \\
\hline $\mathrm{P}$ & $<0.01$ & $<0.01$ & $<0.01$ & & & & & & \\
\hline
\end{tabular}

For abbreviations and statistical details, see Table I.

\section{Bioassay}

The $3^{\text {rd }}$ and $4^{\text {th }}$ instar larvae of $S$. litura were infected with three concentrations of NPV: $\left(2 \times 10^{8} ; 3 \times 10^{8}\right.$ and $4 \times 10^{8}$ POB L ${ }^{-1}$ as stock solution, designated here as NPV-1, NPV-2 and NPV-3. A desired quantity of 10, 15 and $20 \mu$ lobtained from each $1 \mathrm{ml}$ stock NPV suspension was incorporated in an artificial diet. Mortality, pupation, adult emergence and egg eclosion of $S$. litura were determined on single concentration of Spinosad (0.01 $\mathrm{ppm}$ ) and three concentrations of NPV individually, and 
in respective combinations. The NPVs and Spinosad was applied by incorporating it with artificial diets and mixing in shaker for even distribution. Cubes of $2 \mathrm{~mm}^{2}$ from prepared diet were cut and soaked in respective NPV and spinosad concentrations. In this way, different batches of artificial diets were arranged in sequence to provide the test chemicals to the target insects. The pre-starved (12 h) larvae $(n=215 /$ treatment $)$ ) of $3^{\text {rd }}$ and $4^{\text {th }}$ instar from each district were put separately in the plastic vials (base radius $2.4 \mathrm{~cm} \times$ height $6 \mathrm{~cm}$ ). A piece of the artificial diet $\left(2 \mathrm{~mm}^{2}\right)$ from each treatment was given to $3^{\text {rd }}$ and $4^{\text {th }}$ instar larvae until complete consumption. The larvae served with untreated diet were designated as control. After being fed, the larvae were removed and then released in plastic vials containing an artificial diet until the larvae died or pupated. All the bioassays were carried out at $25 \pm 2{ }^{\circ} \mathrm{C}$, $70 \pm 5 \%$ R.H. and L16: D8 h photoperiod. Each treatment was replicated three times, and each bioassay was repeated thrice independently to avoid the phenomenon of pseudoreplication. The data regarding mortality was recorded regularly until pupation. The larvae were poked with a blunt needle and those which were unable to move in a coordinated manner were considered dead (Ma et al., 2008). The data regarding pupation and adult emergence was also recorded thereafter. The emerged adults were allowed to mate freely for each treatment and egg-hatching percentage was also calculated to observe further NPV effect.

\section{Data analysis}

The mortality means were corrected using Abbott's (1925) formula and the data was processed through oneway ANOVA using Minitab 13.2. The synergistic, additive and antagonistic interaction between the treatments were determined by the equation $\mathrm{CTF}=(\mathrm{Oc}-\mathrm{Oe}) / \mathrm{Oe} \times 100$. $\mathrm{CTF}$ represents the cytotoxicity triggering factor where observed mortality (Oc) is calculated by combination of insect derived NPV isolates, and the expected mortality (Oe) is the sum produced by each concentration of NPV isolate used in experiment (Mansour et al., 1966). If the cytotoxicity factor has a positive value $>20$ the interaction is considered synergistic, negative value of 20 or above means antagonistic, while any value between 20 and -20 is considered additive. Where the treatment effects were observed to be significant, the means were compared using Tukey-Kramer (HSD) test at $\mathrm{P}=0.05$ (Sokal and Rohif, 1995).

\section{RESULTS}

Larval mortality of S. litura

In single treatments, the highest larval mortality was observed with application of $\mathrm{Sp}$ in populations from Layyah $\left(\mathrm{F}_{7,71}=264 ; \mathrm{P}<0.01\right)$, followed by populations from Faisalabad $\left(\mathrm{F}_{7,71}=256, \mathrm{P}<0.01\right)$, and $\mathrm{RYK}\left(\mathrm{F}_{7,71}\right.$ $=168 ; \mathrm{P}<0.01)$ districts. The dose rate of NPV3+Sp caused maximum larval mortality in populations from Faisalabad, followed by the populations from Layyah and RYK (Table I) (Fig. 2).
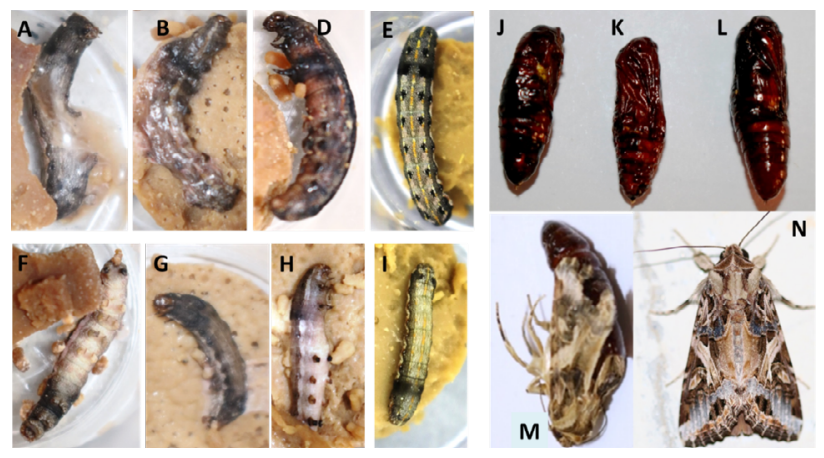

Fig. 2. Different stages of Healthy and treated S. litura, A-D The larvae from $4^{\text {th }}$ Instars showing NPV symptoms treated with NPV1-3+Sp, F-H NPV and Spinosad treated dead larvae of $3^{\text {rd }}$ Instars, EI Healthy (Control) larvae of $4^{\text {th }}$ and $3^{\text {rd }}$ Instars, JKM Severe malformed pupae and Adult after treatment, LN Healthy (Control) Pupa and Adults.
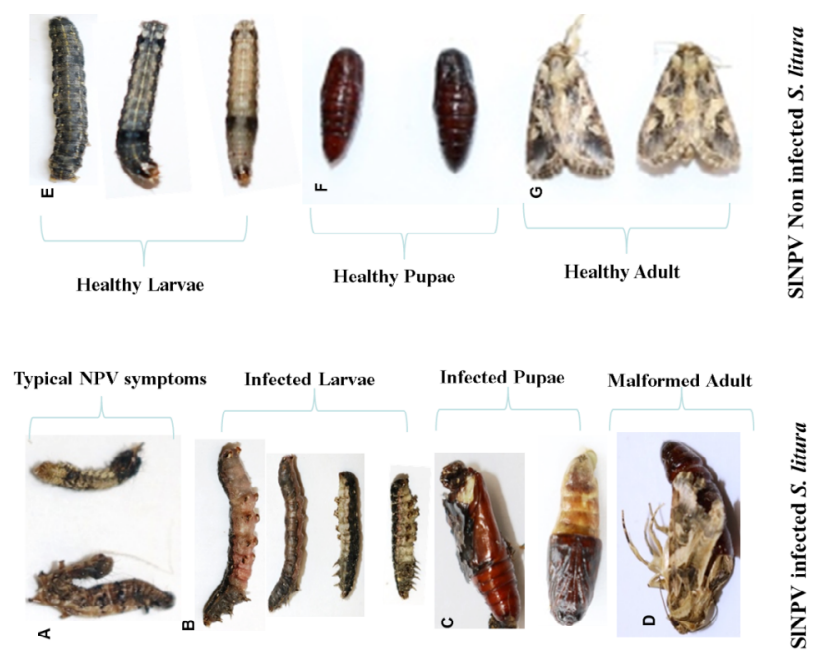

Fig. 3. Graphical Sketch, different stages of healthy and NPV infected larvae of $S$. litura. A, typical NPV infected symptom as attached with walls of vials downward $\left(4^{\text {th }}\right.$ Instars); B, Different NPV infected dead larvae instars; C, NPV infected pupae; $\mathbf{D}$, Malformed NPV infected Adults; E, Healthy larvae; F, Healthy pupae; G, Healthy adults.

For fourth-instar larvae of S. litura, among single treatments, the Spinosad alone caused maximum larval mortality, which was observed in the following order; 
Faisalabad $\left(\mathrm{F}_{7,71}=225, \mathrm{P}<0.01\right)$, Rahim Yar Khan $\left(\mathrm{F}_{7,71}\right.$ $=197, \mathrm{P}<0.01)$, and Layyah $\left(\mathrm{F}_{7,71}=107 ; \mathrm{P}<0.01\right)$, as compared to the untreated control (Table II). Similarly, as it was observed for second-instar larvae, NPV3+Sp treatment showed significantly highest larval mortality for populations from Faisalabad and Layyah districts. The treated larvae showed infection symptoms with swollen and ruptured bodies releasing fluids (Figs. 2 and 3)

Table III. Pupation $(\% \pm$ SE) of third-instar and fourth-instar larvae of $S$. litura from three different field populations of Punjab province, Pakistan after treatment with NPV and Sp, individually, and in combination (NPV+Sp).

\begin{tabular}{|c|c|c|c|}
\hline Treatments & Faisalabad & Layyah & RYK \\
\hline \multicolumn{4}{|c|}{ Third-instar S. litura } \\
\hline Control & $94.8 \pm 0.98 \mathrm{~A}$ & $96.3 \pm 1.18 \mathrm{~A}$ & $97.0 \pm 1.17 \mathrm{~A}$ \\
\hline NPV1 & $73.3 \pm 2.22 \mathrm{~B}$ & $82.3 \pm 2.93 \mathrm{~B}$ & $87.4 \pm 1.73 \mathrm{~B}$ \\
\hline NPV2 & $66.7 \pm 1.57 \mathrm{~B}$ & $70.1 \pm 2.94 \mathrm{C}$ & $71.1 \pm 1.92 \mathrm{C}$ \\
\hline NPV3 & $55.6 \pm 1.57 \mathrm{C}$ & $59.3 \pm 2.59 \mathrm{D}$ & $60.0 \pm 1.12 \mathrm{D}$ \\
\hline $\mathrm{Sp}$ & $41.5 \pm 1.85 \mathrm{D}$ & $50.4 \pm 1.95 \mathrm{D}$ & $48.9 \pm 2.23 \mathrm{E}$ \\
\hline NPV1+ SP & $27.4 \pm 3.41 \mathrm{E}$ & $33.4 \pm 0.00 \mathrm{E}$ & $47.4 \pm 2.06 \mathrm{E}$ \\
\hline $\mathrm{NPV} 2+\mathrm{SP}$ & $8.9 \pm 2.48 \mathrm{~F}$ & $21.5 \pm 1.85 \mathrm{~F}$ & $23.7 \pm 2.74 \mathrm{~F}$ \\
\hline NPV3+ SP & $0.0 \pm 0.00$ & $2.9 \pm 1.17 \mathrm{G}$ & $7.4 \pm 1.73 \mathrm{G}$ \\
\hline $\mathrm{F}$ & 267 & 235 & 253 \\
\hline Df & 7,71 & 7,71 & 7,71 \\
\hline $\mathrm{P}$ & $<0.01$ & $<0.01$ & $<0.01$ \\
\hline \multicolumn{4}{|c|}{ Fourth-instar $S$. litura } \\
\hline Control & $95.6 \pm 1.57 \mathrm{~A}$ & $97.0 \pm 1.61 \mathrm{~A}$ & $98.5 \pm 0.97 \mathrm{~A}$ \\
\hline NPV1 & $79.3 \pm 1.73 \mathrm{~B}$ & $85.2 \pm 1.48 \mathrm{~B}$ & $89.6 \pm 1.61 \mathrm{~B}$ \\
\hline NPV2 & $67.4 \pm 1.73 \mathrm{C}$ & $74.1 \pm 0.74 \mathrm{C}$ & $74.8 \pm 2.42 \mathrm{C}$ \\
\hline NPV3 & $57.8 \pm 2.48 \mathrm{D}$ & $67.5 \pm 1.34 \mathrm{C}$ & $68.1 \pm 1.48 \mathrm{C}$ \\
\hline $\mathrm{Sp}$ & $47.4 \pm 0.74 \mathrm{E}$ & $55.6 \pm 2.23 \mathrm{D}$ & $56.3 \pm 1.61 \mathrm{D}$ \\
\hline $\mathrm{NPV} 1+\mathrm{Sp}$ & $29.6 \pm 1.17 \mathrm{~F}$ & $42.2 \pm 2.24 \mathrm{E}$ & $26.7 \pm 1.57 \mathrm{E}$ \\
\hline $\mathrm{NPV} 2+\mathrm{SP}$ & $15.6 \pm 1.11 \mathrm{G}$ & $28.1 \pm 1.48 \mathrm{~F}$ & $32.6 \pm 1.73 \mathrm{E}$ \\
\hline $\mathrm{NPV} 3+\mathrm{Sp}$ & $3.7 \pm 1.17 . \mathrm{H}$ & $8.9 \pm 3.1 \mathrm{G}$ & $13.3 \pm 1.57 \mathrm{~F}$ \\
\hline $\mathrm{F}$ & 419 & 242 & 342 \\
\hline Df & 7,71 & 7,71 & 7,71 \\
\hline $\mathrm{P}$ & $<0.01$ & $<0.01$ & $<0.01$ \\
\hline
\end{tabular}

For abbreviations and statistical details, see Table I. $n=215 /$ treatment where $\mathrm{n}$ is number of each 3rd and 4th instar larvae individually used in experiment)

Pupation and adult emergence

The combined treatments of NPV+Sp for $3^{\text {rd }}$ larval instars population of RYK region showed lowest pupation and adult emergence as compared to single treatments (Tables III, IV). The morphological and physiological alteration was observed from larval-adult $S$. litura population treated with different concentrations of NPVs+Sp (Fig. 2). Likewise, during bioassay of fourthinstar S. litura, Sp with high dose rate of NPV application against various populations showed decreasing pupation trend $\left(\mathrm{RYK}: \mathrm{F}_{7,71}=342, \mathrm{P}<0.01\right.$; Layyah: $\mathrm{F}_{7,71}=242, \mathrm{P}<$ 0.01; Faisalabad: $\mathrm{F}_{7,71}=419, \mathrm{P}<0.01$ ) (Table IV), however, the adult emergence was in ascending order (Faisalabad: $\mathrm{F}_{7,71}=411, \mathrm{P}<0.01$; Layyah. $\mathrm{F}_{7,71}=229, \mathrm{P}<0.01$; RYK: $\mathrm{F}_{7,71}=166, \mathrm{P}<0.01$ ) (Tables III, IV).

Table IV. Adult emergence $(\% \pm$ SE) from third-instar and fourth-instar larvae of $S$. litura from three different field populations after treatment with NPV and Sp, individually, and in combination (NPV+Sp).

\begin{tabular}{|c|c|c|c|}
\hline Treatments & Faisalabad & Layyah & R Y Khan \\
\hline \multicolumn{4}{|c|}{ Third-instar S. litura } \\
\hline Control & $94.1 \pm 1.34 \mathrm{~A}$ & $95.6 \pm 1.12 \mathrm{~A}$ & $96.3 \pm 1.17 \mathrm{~A}$ \\
\hline NPV1 & $65.9 \pm 1.33 \mathrm{~B}$ & $74.8 \pm 1.85 \mathrm{~B}$ & $80.0 \pm 1.92 \mathrm{~B}$ \\
\hline NPV2 & $55.6 \pm 1.11 \mathrm{C}$ & $62.9 \pm 3.35 \mathrm{C}$ & $71.1 \pm 1.56 \mathrm{C}$ \\
\hline NPV3 & $46.7 \pm 1.57 \mathrm{D}$ & $59.2 \pm 4.44 \mathrm{Cd}$ & $62.2 \pm 1.11 \mathrm{D}$ \\
\hline $\mathrm{Sp}$ & $40.7 \pm 1.73 \mathrm{D}$ & $49.6 \pm 1.17 \mathrm{D}$ & $56.3 \pm 1.61 \mathrm{D}$ \\
\hline $\mathrm{NPV} 1+\mathrm{Sp}$ & $22.9 \pm 1.17 \mathrm{E}$ & $30.4 \pm 3.16 \mathrm{E}$ & $35.5 \pm 1.57 \mathrm{E}$ \\
\hline $\mathrm{NPV} 2+\mathrm{Sp}$ & $4.5 \pm 2.23 \mathrm{~F}$ & $14.1 \pm 2.06 \mathrm{~F}$ & $17.0 \pm 1.61 \mathrm{~F}$ \\
\hline $\mathrm{NPV} 3+\mathrm{Sp}$ & $0.0 \pm 0.00 \mathrm{~F}$ & $0.74 \pm 0.74 \mathrm{G}$ & $3.7 \pm 1.59 \mathrm{G}$ \\
\hline $\mathrm{F}$ & 484 & 166 & 423 \\
\hline Df & 7,71 & 7,70 & 7,71 \\
\hline $\mathrm{P}$ & $<0.01$ & $<0.01$ & $<0.01$ \\
\hline \multicolumn{4}{|c|}{ Fourth instar $S$. litura } \\
\hline Control & $94.8 \pm 1.85 \mathrm{~A}$ & $96.3 \pm 1.61 \mathrm{~A}$ & $97.8 \pm 1.11 \mathrm{~A}$ \\
\hline NPV1 & $72.6 \pm 1.73 \mathrm{~B}$ & $86.6 \pm 2.48 \mathrm{~B}$ & $88.1 \pm 1.48 \mathrm{~A}$ \\
\hline NPV2 & $60.7 \pm 0.74 \mathrm{C}$ & $72.6 \pm 2.82 \mathrm{C}$ & $76.29 \pm 3.86 \mathrm{~B}$ \\
\hline NPV3 & $57.8 \pm 1.11 \mathrm{C}$ & $64.5 \pm 1.57 \mathrm{C}$ & $68.1 \pm 2.89 \mathrm{~B}$ \\
\hline $\mathrm{Sp}$ & $49.6 \pm 1.61 \mathrm{D}$ & $51.9 \pm 1.48 \mathrm{D}$ & $63.7 \pm 2.74 \mathrm{C}$ \\
\hline $\mathrm{NPV} 1+\mathrm{Sp}$ & $34.1 \pm 1.74 \mathrm{E}$ & $37.0 \pm 2.51 \mathrm{E}$ & $45.9 \pm 2.06 \mathrm{D}$ \\
\hline $\mathrm{NPV} 2+\mathrm{Sp}$ & $14.8 \pm 2.15 \mathrm{~F}$ & $24.5 \pm 1.92 \mathrm{~F}$ & $28.9 \pm 1.11 \mathrm{E}$ \\
\hline $\mathrm{NPV} 3+\mathrm{sp}$ & $0.0 \pm 0.00 \mathrm{G}$ & $7.4 \pm 1.34 \mathrm{G}$ & $11.1 \pm 1.57 \mathrm{~F}$ \\
\hline $\mathrm{F}$ & 411 & 229 & 166 \\
\hline df & 7,71 & 7,71 & 7,71 \\
\hline $\mathrm{P}$ & $<0.01$ & $<0.01$ & $<0.01$ \\
\hline
\end{tabular}

For abbreviations and statistical details, see Table I.

Egg eclosion

Maximum egg eclosion in second-instar larvae of $S$. 
litura was observed in larval populations from $\mathrm{RYK}\left(\mathrm{F} \mathrm{F}_{7,71}\right.$ $=28.1 ; \mathrm{P}<0.01)$ and Layyah $\left(\mathrm{F}_{7,71}=32.4 ; \mathrm{P}<0.01\right)$ in both individual and combined treatments. However, minimum egg eclosion was observed in population from Faisalabad $\left(\mathrm{F}_{7,71}=41.6 ; \mathrm{P}<0.01\right)$ at the highest sub-lethal dose rate of NPV (6 x $10^{3} \mathrm{PIB} /$ larva $)$ with sub-lethal dose rate of Sp (0.01ppm) (Tables V). Similarly, in $4^{\text {th }}$ instar, the same trend (RYK: $\mathrm{F}_{7,71}=16.4, \mathrm{P}<0.01$; Layyah: $\mathrm{F}_{7,71}=21.1, \mathrm{P}<$ 0.01; and Faisalabad: $\mathrm{F}_{7,71}=57.2 ; \mathrm{P}<0.01$ ) was observed, where NPV and Spinosad were applied in combination at the dose rates of $\left(6 \times 10^{3} \mathrm{PIB} /\right.$ larva) and $0.01 \mathrm{ppm}$ (Tables V). Overall, eclosion rates decreased significantly in the treatments where higher concentration of NPV and sublethal dose of Sp were applied simultaneously.

Table V. Egg eclosion $(\% \pm$ SE) of third-instar and fourth instar larvae of $S$. litura from three different field populations treated with NPV and Sp, individually, and in combination $(\mathrm{NPV}+\mathrm{Sp})$.

\begin{tabular}{llll}
\hline \multicolumn{1}{l}{ Treatments } & Faisalabad & Layyah & RYK \\
\hline \multicolumn{1}{l}{ Third-instar S. litura } & & \\
NPV1 & $61.5 \pm 4.70 \mathrm{~B}$ & $69.0 \pm 6.40 \mathrm{Ab}$ & $74.4 \pm 4.98 \mathrm{~A}$ \\
NPV2 & $49.5 \pm 6.74 \mathrm{Bc}$ & $58.8 \pm 6.50 \mathrm{Bc}$ & $67.7 \pm 4.95 \mathrm{Ab}$ \\
NPV3 & $38.9 \pm 4.39 \mathrm{Cd}$ & $45.3 \pm 4.77 \mathrm{Cd}$ & $49.4 \pm 4.84 \mathrm{Bc}$ \\
Sp & $25.3 \pm 4.43 \mathrm{De}$ & $36.5 \pm 5.06 \mathrm{Cde}$ & $40.5 \pm 5.56 \mathrm{Cd}$ \\
NPV-1+ Sp & $16.6 \pm 2.18 \mathrm{Ef}$ & $25.3 \pm 6.67 \mathrm{De}$ & $34.1 \pm 7.04 \mathrm{Cd}$ \\
NPV-2 + Sp & $9.9 \pm 3.02 \mathrm{Ef}$ & $16.6 \pm 6.00 \mathrm{Ef}$ & $19.7 \pm 9.60 \mathrm{De}$ \\
NPV-3 + Sp & $0.00 \pm 0.00 \mathrm{~F}$ & $0.00 \pm 0.00 \mathrm{~F}$ & $1.70 \pm 1.15 \mathrm{E}$ \\
Control & $83.4 \pm 5.63 \mathrm{~A}$ & $90.6 \pm 1.61 \mathrm{~A}$ & $92.4 \pm 2.62 \mathrm{~A}$ \\
F & 41.6 & 32.4 & 28.1 \\
df & 7,71 & 7,71 & 7,71 \\
P & $<0.01$ & $<0.01$ & $<0.01$ \\
Fourth-instar S. litura & & \\
NPV1 & $72.2 \pm 4.92 \mathrm{~B}$ & $85.6 \pm 6.35 \mathrm{~A}$ & $92.4 \pm 1.92 \mathrm{~A}$ \\
NPV2 & $62.8 \pm 5.00 \mathrm{Bc}$ & $72.4 \pm 5.15 \mathrm{Ab}$ & $78.3 \pm 2.39 \mathrm{Ab}$ \\
NPV3 & $46.3 \pm 6.01 \mathrm{Cd}$ & $55.6 \pm 10.09 \mathrm{Bc}$ & $65.2 \pm 3.88 \mathrm{Abc}$ \\
Sp & $34.8 \pm 3.51 \mathrm{De}$ & $45.7 \pm 4.77 \mathrm{Bcd}$ & $54.7 \pm 7.45 \mathrm{Bcd}$ \\
NPV-1+ Sp & $23.1 \pm 3.76 \mathrm{Ef}$ & $34.5 \pm 10.27 \mathrm{Cde}$ & $40.0 \pm 6.45 \mathrm{Cde}$ \\
NPV-2 + Sp & $17.0 \pm 2.76 \mathrm{Fg}$ & $23.5 \pm 4.18 \mathrm{De}$ & $29.9 \pm 4.74 \mathrm{De}$ \\
NPV-3 + Sp & $4.9 \pm 2.00 \mathrm{G}$ & $11.8 \pm 3.20 \mathrm{E}$ & $10.2 \pm 2.87 \mathrm{E}$ \\
Control & $92.7 \pm 1.59 \mathrm{~A}$ & $93.9 \pm 1.92 \mathrm{~A}$ & $87.9 \pm 16.19 \mathrm{~A}$ \\
F & 57.2 & 21.1 & 16.4 \\
Df & 7,71 & 7,71 & 7,71 \\
P & $<0.01$ & $<0.01$ & $<0.01$ \\
\hline
\end{tabular}

For abbreviations and statistical details, see Table I.

\section{DISCUSSION}

Lepidoptera comprises of many agricultural and forest pests, which can be controlled by theuse of biological insecticides (Nathan and Kalaivani, 2006). Excessive use of synthetic chemical insecticide has created insecticide resistance, pest resurgence along with environmental and health complications (Cherry et al., 1997), which urges the researchers to find out some environmentally safer control agents to control the agriculturally important insect pests. Combining microbes with bio- rational insecticides is an ideal tool to overcome resistance in insect pests (Ahmad et al., 2018). S. litura is one of the most destructive pests that cause serious economic losses to many cash crops. It has been reported that entomopathogens have the ability to tackle insecticide resistance related issues. The rotation of control materials also helps to lessen the onset of insecticide resistance (Zahn and Morse, 2013). In current study S. litura showed retarded growth, decreased life span of male and female and increased larval and pupal duration after viral infection. The enhanced pathogenicity of NPVs has been observed against different vegetable and ornamental crops (Arrizubieta et al., 2014; Rios-Velasco et al., 2011; Ahmad et al., 2018). The pathogenicity of viral infection varies in different larval instars because of attraction of neonate larvae towards light, being very active and consumes large areas of leaf during feedings (Gothama et al., 1995; Smits and Vlak, 1988). A similar kind of response was also reported by other researchers (Nathan and Kalaivani, 2005, 2006) for Azadirachtin (AZA) and NPVs against the S. litura. Moreover, increase in pupal duration from third to fourth-instar larvae of $S$. frugiperda has been observed by Zamora-Avilés et al. (2013). The cutworm larvae died more rapidly at the higher and combined dose rate of AZA and S. litura derived NPV (SpltNPV). In contrast, the contradictory result was also obtained by Wakil et al. (2012), who found that fourth and fifth-instar larvae of $H$. armigera were more susceptible to viral infection than the second-instar larvae. The present study showed that $\mathrm{Sp}$ is more effective against forth instar larvae in all tested populations. Wang and co-workers (Wang et al., 2009, 2013) obtained similar results at low concentration of Spinosad against $H$. armigera and $S$. exigua. It has been reported that $\mathrm{Sp}$ has a novel mode of action primarily acting on nicotinic acetylcholine receptor and further on butyric acid receptors resulting in paralysis of insects (Capinera and Froeba, 2014). Spinosad delays egg hatching ability, fecundity, extend larval developmental time, reduce- weight gain, pupation ratio, pupal weight, adult emergence and adult longevity, which makes the insect pest more vulnerable against entomopathogenic insect (Wang et al., 2013; Malik et al., 
2016). Organophosphates, carbamates, pyrethroids, and Bacillus thuringiensis $(\mathrm{Bt})$ resistance in diamondback moth has been managed by using Spinosad (Zhao et al., 2006). The combined application of insecticides with myco-insecticide is an interesting strategy to control the important insect pests owing to the low concentration of insecticide which reduces the mechanism of resistance (Malik et al., 2016). The western corn rootworm (WCR), Diabrotica virgifera was controlled by the combined application of entomopathogen and pesticides under field condition (Rauch et al., 2017).

Previously, several researchers have reported higher mortalities of lepidopteron pest with combined application of NPV and Spinosad as compared to single application in both field and laboratory trials (Jackson et al., 2014; Mendez et al., 2002; Figueroa et al., 2015). In current bioassay, similar results were observed. Synergistic effects were found when high concentration of NPV with spinosad was applied against third and fourth-instar larvae of $S$. litura which is in accordance with the findings of (Figueroa et al., 2015), who observed synergistic interaction when NPV and $\mathrm{Sp}$ were applied against $S$. frugiperda (Lepidoptera: Noctuidae). However, the synergistic effect of NPV and Spinosad from our findings is in contrast with the observation of Mendez et al. (2002), who reported independent or antagonistic effect of NPV and Spinosad against $S$. frugiperda. The same effect was also reported by many scientists for NPV alone or with different bio rational insecticide against insect pest (Ahmad et al., 2018; Qayyum et al., 2015; Wakil et al., 2012; Pineda et al., 2014). The possible reason of NPV-Spinosad synergism is because of the physiological changes or chemical pressures caused by bio-rational insecticides in insects making them more susceptible to occlusion bodies. After infection, NPV spores easily penetrate in insect cuticle and subsequently $\mathrm{OB}$ productions increases causing larvae to become pale in color. The insects slightly swell and often move towards higher point of host plants and then ultimately die (Nathan et al., 2005; Kumar et al., 2008). It has been reported that virus infection prolonged larval molting duration because insect showed susceptibility against viral insecticides (Kumar et al., 2008). On the other hand, contrary to our results, the effect of antagonism at higher dose rate of NPV with imidacloprid has been observed (Trang and Chaudhari, 2002). In the present study, the antagonistic effect was found with low dose rate of Spinosad in combination with NPV against S. litura larvae. The independent or antagonistic interaction in this study could be due to decreased feeding or a change of gut pH (El-Helaly and El-bendary, 2013). The three different geographical populations of $S$. litura showed different mortality response to NPV and Spinosad, therefore, it is also important to observe the resistance development against NPVs and spinosad in Spodoptera population. This is the first study to elucidate the dose dependent synergistic and antagonistic effect of spinosad and native distinct NPV isolates against three different geographical population of S. litura. The high mortality and dose dependent distinct response in Faisalabad population contrary to Rahim Yar Khan Population of $S$. litura could be due to different geographical NPV isolate and insecticide resistance development in $S$. litura populatuon. Now, there is a need to fully characterize these locally isolated $S$. litura based NPVs on molecular level and test its effectiveness combined with some other chemical insecticides. The efficacy testing of various other NPVs against laboratory developed susceptible, resistance and field population of $S$. litura is under progress.

\section{CONCLUSIONS}

The present investigation is a novel study in which the indigenous isolates of NPV were applied alone and in combination with an insecticide for the first time against $S$. litura at various life stages. Our results indicate that among several single and combined treatments, NPV and $\mathrm{Sp}$ showed higher mortalities against all the larval populations of $S$. litura. Furthermore, the combination of sub-lethal doses of NPV+Sp could be a new and cost effective strategy against $S$. litura in IPM regimes. But it is also very important to study the difference in mortalities against different geographical population for specific NPVs. The decrease in use of synthetic insecticides mitigates the insecticide resistance problem and proves less hazardous for non-target organisms. However, laboratory trials on the efficiency of Sp+NPV mixtures requires validation in field studies as a potential IPM strategy against $S$. litura in vegetable and main crop growing areas of Pakistan.

\section{ACKNOWLEDGEMENTS}

The authors, JNA, SJNA, AMB, and IA acknowledge the financial support from PAK 3004 Framework for Pak-Norway Institutional Co-operation Programme (FICP). The authors also acknowledge the efforts of Mr. Abdullah (laboratory assistant) for rearing and maintenance of insect culture for all the experiments.

\section{Statement of conflict of interest}

Authors declare no conflict of interest. 


\section{REFERENCES}

Abbott, W.S., 1925. A method of computing the ef fectiveness of an insecticide. J. Econ. Entomol., 18: 265-267.

Ahmad, S., Cheema, H.M.N., Khan,A.A., Khan, S.A. and Ahmad, J.N., 2019. Resistance status of Helicoverpa armigera against Bt cotton in Pakistan. Transg. Res., 28: 199-212. https://doi.org/10.1007/s11248-01900114-9

Ahmad, J.N., Ahmad, S.J.N., Aslam, A., Ahmad, Muhammad A.A., Contaldo, N., Paltrinieri, S. and Bertaccini, A., 2017. Molecular and biologic characterization of a phytoplasma associated with Brassica campestris phyllody disease in Punjab province, Pakistan. Eur. J. Pl. Pathol., 149: 117125. https://doi.org/10.1007/s10658-017-1170-4

Ahmad, J.N., Jafir, M., Javed, M.W., Maqsood. S. and Ahmad, S.J.N., 2019. Molecular identification and sequence analysis of the dusky cotton bug, Oxycarenus hyalinipennis (Hemiptera:Lygaiedae) infesting cotton in Pakistan. Pakistan J. Zool., 51: 1-4. https://doi.org/10.17582/journal.pjz/2019.51.2.SC1

Ahmad, J.N., Sharif, T., Ahmad, S.J.N., Maqsood, S.A. and Zaffar, F., 2019. Molecular identification and Sequence analysis of fruit flies of genus Bactrocera (Diptera: Tephritidae) in Pakistan. Pakistan J. Zool., 51: 2275-2280. https://doi.org/10.17582/journal. pjz/2019.51.6.2275.2280

Ahmad, J.N., Mushtaq, R., Ahmad, S.J.N., Maqsood, S., Ahuja, A. and Bones, A.M., 2018. Molecular identification and pathological characteristics of native isolated NPV against Spodoptera litura (Fabricius) in Pakistan. Pakistan J. Zool,. 50: 2229-2237. https://doi.org/10.17582/journal. pjz/2018.50.6.2229.2237

Ahmad, J.N., Renaudin, J. and Eveillard, S., 2014. Expression of defence genes in stolbur phytoplasma infected tomatoes, and effect of defence stimulators on disease development. Eur. J. Pl. Pathol., 139: 3951. https://doi.org/10.1007/s10658-013-0361-x

Ahmad, J.N., Pracros, P., Garcion, C., Teyssier, E., Renaudin, J., Hernould, M., Gallusci, P. and Eveillard, S., 2013. Effects of stolbur phytoplasma infection on DNA methylation processes in tomato plants. Pl. Pathol, 62: 205-216. https://doi. org/10.1111/j.1365-3059.2012.02605.x

Ahmad, M., Iqbal, Arif, M. and Ahmad, M., 2007. Occurrence of insecticide resistance in field populations of Spodoptera litura (Lepidoptera: Noctuidae) in Pakistan. Crop Prot., 26: 809-817. https://doi.org/10.1016/j.cropro.2006.07.006
Ahmad, M., Sayyed, A.H., Saleem, M.A. and Ahmad, M., 2008. Evidence for field evolved resistance to newer insecticides in Spodoptera litura (Lepidoptera: Noctuidae) from Pakistan. Crop Prot., 27: 13671372. https://doi.org/10.1016/j.cropro.2008.05.003

Amante, M., Schöller, M., Hardy, I.W.C. and Russo, A., 2017. Reproductive biology of Holepyris sylvanidis (Hymenoptera: Bethylidae). Biol. Contr., 106: 1-8. https://doi.org/10.1016/j.biocontrol.2016.12.004

Arrizubieta, M., Simón, O., Torres-Vila, L.M., Figueiredo, E., Mendiola, J., Mexia, A., Caballero, P. and Williams, T., 2016. Insecticidal efficacy and persistence of a co-occluded binary mixture of Helicoverpa armigera nucleopolyhedrovirus (HearNPV) variants in protected and field-grown tomato crops on the Iberian Peninsula. Pest Manage. Sci., 72: 660-670. https://doi.org/10.1002/ps.4035

Arrizubieta, M., Williams, T., Caballero, P. and Simón, O., 2014. Selection of a nucleopolyhedrovirus isolate from Helicoverpa armigera as the basis for a biological insecticide. Pest Manage. Sci., 70: 967976. https://doi.org/10.1002/ps.3637

Aydin, H. and Gürkan, M.O., 2006. The efficacy of spinosad on different strains of Spodoptera littoralis (Boisduval) (Lepidoptera: Noctuidae). Turk J. Biol., 30: 5-9.

Bhandari, K., Sood, P., Mehta, P.K., Choudhary, A. and Prabhakar, C.S., 2009. Effect of botanical extracts on the biological activity of granulosis virus against Pieris brassicae. Phytoparasitica, 37: 317-322. https://doi.org/10.1007/s12600-009-0047-2

Capinera, J.L. and Froeba, J.G., 2014. Behavioral responses of Schistocerca americana (Orthoptera: Acrididae) to Azadirex (neem)-treated host plants. J. econ. Ent., 100: 117-122. https://doi.org/10.1093/ jee/100.1.117

Cherry, A.J., Parnell, M.A., Grzywacz, D. and Jones, K.A., 1997. The optimization of in vivo Nuclear Polyhedrosis Virus production in Spodoptera exempta (Walker) and Spodoptera exigua (Hübner). J. Inverebt. Pathol., 70: 50-58. https://doi. org/10.1006/jipa.1997.4664

Cook, S.P., Webb, R.E., Podgwaite, J.D. and Reardon, R.C., 2003. Increased mortality of gypsy moth Lymantria dispar (L.) (Lepidoptera: Lymantriidae) exposed to gypsy moth nuclear polyhedrosis virus in combination with the phenolic gycoside salicin. $J$. Econ. Entomol., 96: 1662-1667.

Dhir, B.C., Mohapatra, H.K. and Senapati, B., 1992. Assessment of crop loss in groundnut due to tobacco caterpillar, Spodoptera litura (F.). Ind. J. Pl. Prot., 20: 215-217. 
El-Helaly, A.A. and El-bendary, H.M., 2013. Impact of spinosad and nucleopolyhedrovirus alone and in combination against the cotton leaf worm Spodoptera littoralis under laboratory. Appl. Sci. Rep., 2 :17-21.

Figueroa, J.I., Coronado, R.E., Pineda, S., Chavarrieta, J.M. and Martínez-Castillo, A.M., 2015. Mortality and food consumption in Spodoptera frugiperda (Lepidoptera: Noctuidae) larvae treated with spinosad alone or in mixtures with a nucleopolyhedrovirus. Fla. Entomol., 98: 10091011. https://doi.org/10.1653/024.098.0340

Gothama, A.A.A., Sikorowski, P.P. and Lawrence, G.W., 1995. Interactive effects of Steinernema carpocapsae and Spodoptera exigua nuclear polyhedrosis virus on Spodoptera exigua larvae. J. Inverteb. Pathol., 66: 270-276. https://doi.org/10.1006/jipa.1995.1100

Green, T.B., Shapiro, A., White, S., Rao, S., Mertens, P.P.C., Carner, G. and Becnel, J.J., 2006. Biological and molecular studies of a cypovirus from the black fly Simulium ubiquitum (Diptera: Simuliidae). J. Inverteb. Pathol., 95: 26-32. https://doi. org/10.1016/j.jip.2006.10.006

Hu, Z., Chen, X. and Sun, X., 2003. Molecular biology of insect viruses. In: Advances in microbial control of insect pests (ed. R.K. Upadhyay). Springer US, Boston, MA, pp. 83-107. https://doi. org/10.1007/978-1-4757-4437-8_5

Jackson, D.M., Shapiro, M. and Merle, B. 2014. Shepardeffects of spinosad and neem on the efficacy of nucleopolyhedrovirus on pickleworm larvae. J. Agric. Urban Ent., 30: 28-37. https://doi. org/10.3954/JAUE13-10.1

Kumari, V. and Singh, N.P., 2009. Spodoptera litura nuclear polyhedrosis virus (NPV-S) as a component in integrated pest management (IPM) of Spodoptera litura (Fab.) on cabbage. J. Biopestic., 2: $84-86$.

Kumar, S.N., Murugan, K. and Zhang, W., 2008. Additive interaction of Helicoverpa armigera nucleopolyhedrovirus and Azadirachtin Nachimuthu. Biol. Contr., 53: 869-880. https://doi. org/10.1007/s10526-007-9115-Z

Ma, X.-M., Liu, X.-X., Ning, X., Zhang, B., Han, F., Guan, X.-M., Tan, Y.-F., Zhang, Q.-W., 2008. Effects of Bacillus thuringiensis toxin Cry1Ac and Beauveria bassiana on Asiatic corn borer (Lepidoptera: Crambidae). J. Inverteb. Pathol., 99: 123-128. https://doi.org/10.1016/j.jip.2008.06.014

Malik, M.A., Manzoor, M., Ali, H., Muhammad, A., Islam, S.U., Qasim, M., Ahmad, N., Idrees, A., Muhammad, A. and Saqib, H.S.A., 2016. Evaluation of imidacloprid and entomopathogenic fungi, Beauveria bassiana against the red palm weevil Rhynchophorus ferrugineus (Coleoptera: Curculionidae). J. Ent. Zool. Stud., 4: 262-268.

Manzoor, M., Ahmad, J.N., Giblin-Davis, R.M. and Arif, M.J., 2018. Molecular Identification and Phylogenetic Analysis of Distinct Geographical Populations of Rhynchophorus ferrugineus (Olivier) (Coleoptera: Curculionidae) in Pakistan. Int. J. Agric. Biol., 20: 1997-2004.

Mansour, N.A., Eldefrawi, M.E., Toppozada, A. and Zeid, M., 1966. Toxicological studies on the Egyptian cotton leaf worm, Prodenia litura. VI. Potentiation and antagonism of organophosphorus and carbamate insecticides. J. econ. Ent., 59: 307-311. https://doi. org/10.1093/jee/59.2.307

Mendez, Walter, A., Valle, J., Ibarra, J.E., Cisneros, J., Penagos, D.I. and Williams, T., 2002. Spinosad and nucleopolyhedrovirus mixtures for control of Spodoptera frugiperda (Lepidoptera: Noctuidae) in maize. Biol. Contr., 25:195-206. https://doi. org/10.1016/S1049-9644(02)00058-0

Mertz, F.P and Yao, R.C., 1990. Saccharopolyspora spinosa sp. nov. Isolated from soil collected in a Sugar Mill Rum Still. Int. J. Syst. Bacteriol., 40: 3439

Nathan, S.S. and Kalaivani, K., 2005. Efficacy of nucleopolyhedrovirus and azadirachtin on Spodoptera litura Fabricius (Lepidoptera: Noctuidae). Biol. Contr., 34: 93-98. https://doi. org/10.1016/j.biocontrol.2005.03.001

Nathan, S.S. and Kalaivani, K., 2006. Combined effects of azadirachtin and nucleopolyhedrovirus (SpltNPV) on Spodoptera litura Fabricius (Lepidoptera: Noctuidae) larvae. Biol. Contr., 39: 96-104. https:// doi.org/10.1016/j.biocontrol.2006.06.013

Pineda, S., Pérez-Robledo, C.A., Hernández, R.E., Figueroa de la Rosa, J.I., Chavarrieta, J.M. and Martínez, A.M., 2014. Combined and individual effects of a nucleopolyhedrovirus and azadirachtin on the mortality and maize-leaf consumption of Spodoptera frugiperda. Phytoparasitica, 42: 571578. https://doi.org/10.1007/s12600-014-0395-4

Popham, H.J.R., Nusawardani, T. and Bonning, B.C., 2016. Introduction to the use of Baculoviruses as biological insecticides. In: Baculovirus and insect cell expression protocols (ed. D.W. Murhammer). Springer New York, New York, NY. pp. 383-392. https://doi.org/10.1007/978-1-4939-3043-2_19

Prayogo, Y., Tengkano, W. and Marwoto, D., 2005. Prospect of entomopathogenic fungus Metarhizium anisopliae to control Spodoptera litura on soybean. Jurnal Litbang Pertanian, 24: 19-26.

Qayyum, M.A., Wakil, W., Arif, M.J. and Sahi, S.T., 2015. 
Bacillus thuringiensis and Nuclear Polyhedrosis Virus for the enhanced bio-control of Helicoverpa armigera. Int. J. Agric. Biol., 17:1043-1048. https:// doi.org/10.17957/IJAB/15.0025

Rao, G.V.R., Kumar, C.S., Sireesha, K. and Kumar, P.L., 2015. Role of nucleopolyhedroviruses (NPVs) in the management of lepidopteran pests in Asia. In: Biocontrol oflepidopteran pests: Use of soil microbes and their metabolites (eds. K.S. Sree and A. Varma). Springer International Publishing, Cham, pp. 11-52. https://doi.org/10.1007/978-3-319-14499-3_2

Rauch, H., Steinwender, B.M., Mayerhofer, J., Sigsgaard, L., Eilenberg, J., Enkerli, J., Zelger, R. and Strasser, H., 2017. Field efficacy of Heterorhabditis bacteriophora (Nematoda: Heterorhabditidae), Metarhizium brunneum (Hypocreales: Clavicipitaceae), and chemical insecticide combinations for Diabrotica virgifera virgifera larval management. Biol. Contr., 107: 1-10. https://doi.org/10.1016/j.biocontrol.2017.01.007

Rios-Velasco, C., Gallegos-Morales, G., RincónCastro, M.C.D., Cerna-Chávez, E., SánchezPeña, S.R. and Siller, M.C., 2011. Insecticidal activity of native isolates of Spodoptera frugiperda multiple nucleopolyhedrovirus from soil samples in Mexico. Fla Entomol., 94: 716-718. https://doi. org/10.1653/024.094.0346

Saljoqi, A.-U.-R., Haq, R.u., Haq, E.-u.-., Khan, J. and Ali, G., 2015. Rearing of Spodoptera litura (Fabricius) on different artificial diets and its parasitization with Trichogramma chilonis (Ishii). Pakistan J. Zool., 47: 169-175.

Shad, S.A., Sayyed, A.H., Fazal, S., Saleem, M.A., Zaka, S.M. and Ali, M., 2012. Field evolved resistance to carbamates, organophosphates, pyrethroids, and new chemistry insecticides in Spodoptera litura Fab. (Lepidoptera: Noctuidae). J. Pestic. Sci., 85: 153162. https://doi.org/10.1007/s10340-011-0404-z

Shareef, M.Z., Ahmad, S.J.N., Tahir, M., Ziaf, K., Zhang, S.H. and Ahmad, J.N., 2019. Molecular identification and characterisation of phytoplasma associated with carrot, cabbage and onion crop and their putative insect vectors in Punjab, Pakistan. Pak. J. agric. Sci. 56: 407-414.

Shaurub, E.-S.H., El-Meguid, A.A. and Abd El-Aziz, N.M., 2014. Effect of individual and combined treatment with Azadirachtin and Spodoptera littoralis multicapsid Nucleopolyhedrovirus (SpliMNPV, Baculoviridae) on the Egyptian Cotton Leafworm Spodoptera littoralis (Boisduval) (Lepidoptera: Noctuidae). Ecol. Balk., 6: 93-100.

Shapiro, A., Green, T.B., Rao, S., White, S., Carner,
G., Mertens, P.P.C. and Becnel, J.J., 2005. Morphological and molecular characterization of a Cypovirus (Reoviridae) from the Mosquito Uranotaenia sapphirina (Diptera: Culicidae). $J$. Virol., 79: 9430-9438. https://doi.org/10.1128/ JVI.79.15.9430-9438.2005

Smits, P.H. and Vlak, J.M., 1988. Biological activity of Spodoptera exigua nuclear polyhedrosis virus against S. exigua larvae. J. Inverteb. Pathol., 51: 107114. https://doi.org/10.1016/0022-2011(88)90066-3

Sokal, R.R. and Rohlf, F.J., 1995. Biometry: The principles and practice of statistics in biological research. 3rd Edition, W.H. Freeman and Co., New York.

Sparks, T.C., Thompson, G.D., Kirst, H.A., Hertlein, M.B., Larson, L.L., Worden, T.V. and Thibault, S.T., 1998. Biological activity of the spinosyns, new fermentation derived insect control agents, on tobacco budworm (Lepidoptera: Noctuidae) larvae. J. econ. Ent., 91:1277-1283. https://doi.org/10.1093/ jee/91.6.1277

Tang, X.-X., Sun, X.-L., Pu, G.-Q., Wang, W.-B., Zhang, C.-X. and Zhu, J., 2011. Expression of a neurotoxin gene improves the insecticidal activity of Spodoptera litura nucleopolyhedrovirus (SpltNPV). Virus Res., 159: 51-56. https://doi.org/10.1016/j. virusres.2011.04.025

Trang, T.T.K., Chaudhari, S., 2002. Bioassay of nuclear polyhedrosis virus (npv) and in combination with insecticide on Spodoptera litura (Fab). OmonRice, 10:45-53.

Wakil, W., Ghazanfar, M.U., Nasir, F., Qayyum, M.A. and Tahir, M., 2012. Insecticidal efficacy of Azadirachta indica, Nucleopolyhedrovirus and chlorantraniliprole singly or combined against field populations of Helicoverpa armigera Hübner (Lepidoptera: Noctuidae). Chil. J. agric. Res., 72: 53-61. https://doi.org/10.4067/S071858392012000100009

Wang, D., Gong, P., Li, M., Qiu, X. and Wang, K., 2009. Sublethal effects of spinosad on survival, growth and reproduction of Helicoverpa armigera (Lepidoptera: Noctuidae). Pest Manage. Sci., 65: 223-227. https:// doi.org/10.1002/ps.1672

Wang, D., Wang, Y.-M., Liu, H.-Y., Xin, Z. and Xue, M., 2013. Lethal and sublethal effects of spinosad on Spodoptera exigua (Lepidoptera: Noctuidae). $J$. econ. Ent., 106: 1825-1831. https://doi.org/10.1603/ EC12220

Zahn, D.K. and Morse, J.G., 2013. Investigating alternatives to traditional insecticides: Effectiveness of entomopathogenic fungi and Bacillus 
thuringiensis against citrus thrips and avocado thrips (Thysanoptera: Thripidae). J. econ. Ent., 106: 64-72. https://doi.org/10.1603/EC10441

Zamora-Avilés, N., Alonso-Vargas, J., Pineda, S., IsaacFigueroa, J., Lobit, P., Martínez-Castillo, A.M., 2013. Effects of a nucleopolyhedrovirus in mixtures with azadirachtin on Spodoptera frugiperda (J. E. Smith) (Lepidoptera: Noctuidae) larvae and viral occlusion body production. Biol. Sci. Technol., 23: 521-534. https://doi.org/10.1080/09583157.2013.78 8133

Zhang, S., Wu, F., Li, Z., Lu, Z., Zhang, X., Zhang, Q. and Liu, X., 2015. Effects of Nucleopolyhedrovirus Infection on the development of Helicoverpa armigera (Lepidoptera: Noctuidae) and expression of Its 20-hydroxyecdysone- and juvenile hormonerelated genes. Fla. Entomol., 98: 682-689. https:// doi.org/10.1653/024.098.0243

Zhao, J.Z., Collins, H.L., Li, Y.X., Mau, R.F.L., Thompson, G.D., Hertlein, M., Andaloro, J.T., Boykin, R. and Shelton, A.M., 2006. Monitoring of diamondback moth (Lepidoptera: Plutellidae) resistance to spinosad, indoxacarb, and emamectin benzoate. J. econ. Ent., 99: 176-181. 